\title{
Upaya Meningkatkan Kemampuan Menggunting Pada Anak Usia Dini Melalui Media Papercraft
}

\author{
Ni Nyoman Novita Angginingsih ${ }^{*}$, Nice Maylani Asril2, Dewa Gede Firstia \\ Wirabrata $^{3}$
}

1,2,3 Jurusan Pendidikan Guru Pendidikan Anak Usia Dini, STKIP Modern, Ngawi, Indonesia

\section{ART I CLE I N F O}

Article history:

Received 27 April 2021

Revised 30 April 2021

Accepted 01 Juli 2021

Available online 25 Agustus 2021

Kata Kunci:

Kemampuan Menggunting, Media, Papercraft

Keywords:

Cutting Skills, Media, Papercraft

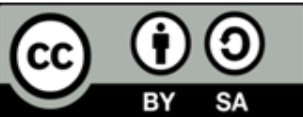

This is an open access article under the CC BY-SA license.

Copyright $(2021$ by Author. Published by Universitas Pendidikan Ganesha.

\begin{abstract}
A B S T R A K
Masih banyak anak yang memiliki keterampilan motorik rendah. Hal ini disebabkan karena kemampuan motorik anak jarang dilatih. Selain itu, kurangnya media pembelajaran yang dapat memfasilitasi anak dalam belajar. Penelitian ini bertujuan untuk mengembangkan media papercraft yang dapat meningkatkan kemampuan menggunting pada anak. Jenis penelitian ini adalah penelitian pengembangan dengan model yang digunakan yaitu ADDIE. Subjek pada penelitian ini yaitu 2 orang ahli media pembelajaran dan 2 orang ahli materi pelajaran. Metode yang digunakan dalam mengumpulkan data yaitu observasi, wawancara, dokumentasi, dan kuesioner. Instrumen yang digunakan dalam mengumpulkan data yaitu kuesioner. Teknik analisis data yang digunakan pada penelitian pengembangan ini yaitu menggunakan teknik analisis statistik deskriptif kualitatif dan statistik deskriptif kuantitatif. Hasil penelitian yaitu hasil uji dari ahli isi mata pelajaran mendapatkan nilai 1,00 sehingga berada pada kualifikasi sangat tinggi dan hasil uji dari ahli media pembelajaran mendapatkan nilai 1,00 (sangat tinggi). Dapat disimpulkan bahwa media yang dikembangkan berupa media papercraft layak diterapkan dalam pembelajaran untuk anak usia dini. Implikasi penelitian ini yaitu media yang dikembangkan dapat memudahkan siswa dalam belajar sehingga dapat meningkatkan kemampuan motorik pada anak usia dini.
\end{abstract}

\begin{abstract}
A B S TRACT
There are still many children who have low motor skills. This is because children's motor skills are rarely trained. In addition, the lack of learning media that can facilitate children in learning. This study aims to develop papercraft media that can improve children's cutting skills. This type of research is development research with the model used is ADDIE. The subjects in this study were 2 learning media experts and 2 subject matter experts. The methods used in collecting data are observation, interviews, documentation, and questionnaires. The instrument used in collecting data is a questionnaire. The data analysis technique used in this development research is using qualitative descriptive statistical analysis techniques and quantitative descriptive statistics. The results of the research are the test results from subject content experts get a score of 1.00 so that they are in a very high qualification and test results from learning media experts get a score of 1.00 (very high). It can be concluded that the media developed in the form of papercraft media is feasible to be applied in learning for early childhood. The implication of this research is that the developed media can facilitate students in learning so that they can improve motor skills in early childhood.
\end{abstract}

\section{PENDAHULUAN}

Pendidikan anak usia dini adalah jenjang pendidikan awal yang ditempuh oleh anak sebelum memasuki sekolah dasar. Pendidikan anak usia dini bertujuan untuk menumbuh kembangkan potensi dan keahlian anak sehingga memiliki kesiapan saat memasuki sekolah dasar (Aisyah, 2017; Iswantiningtyas \& Wulansari, 2018; Sari \& Setiawan, 2012). Hal ini merupakan upaya memberikan rangsangan pendidikan bagi anak (Mardliyah et al., 2020; Wulandari \& Suparno, 2020). Pada masa ini anak mengalami perkembangan yang sangat cepat sehingga perlu diperhatikan. Pendidikan awal sangat penting dalam menstimulasi pertumbuhan anak. Salah satu keterampilan yang perlu dikembangkan pada anak usia dini yaitu kemampuan motorik (Darmiatun \& Mayar, 2019; Pratiwi \& Rahmah, 2019). Keterampilan motorik 
pada anak akan membuat anak menjadi mandiri seperti makan dengan sendok, dan membalikan halaman buku (Nurwita, 2019). Untuk dapat meningkatkan kemampuan motorik salah satu kegiatan sederhana yang dapat dilakukan yaitu melatih anak dengan cara menggunting. Kegiatan ini dapat melatih kesabaran, ketelitian, serta menstimulasi kekuatan jari. Kegiatan seperti ini dapat mengembangkan motorik anak usia dini.

Permasalahan yang terjadi saat ini yaitu masih banyak anak yang memiliki keterampilan motorik rendah (Darmiatun \& Mayar, 2019; Pratiwi \& Rahmah, 2019). Hal ini disebabkan karena kemampuan motorik anak jarang dilatih (Lestariani et al., 2019). Berdasarkan hasil observasi dan wawancara yang dilakukan di TK Negeri Desa Tukadmungga, proses pembelajaran anak saat ini menggunakan grup WhatsApp dan Zoom karena pandemi covid-19 belum berakhir. Banyaknya perubahan dalam melaksanaan pembelajaran membuat banyak kendala yang dihadapi oleh anak, guru, maupun orang tua saat melakukan pembelajaran daring. Hal ini membuat orang tua sebagai pendidik di rumah dan anak harus beradaptasi dengan keadaan seperti ini. Interaksi antara guru dan anak juga sangat terbatas, sehingga orangtua harus banyak meluangkan waktu untuk mendampingi anak saat melaksanaan proses pembelajaran daring di rumah. Anak usia dini tidak dapat belajar secara mandiri dan membutuhkan keterlibatan orang tua sebagai pendamping. Selain itu anak membutuhkan orang tua sebagai pemandu dalam pembelajaran daring (Harahap et al., 2021). Proses pembelajaran yang dilakukan secara daring, membuat orang tua beranggapan anak akan ketergantungan dengan smartphone. Selain itu, guru juga belum menggunakan media pembelajaran saat proses pembelajaran daring sehingga membuat suasana belajar monoton. Hal ini disebabkan karena guru sulit menemukan media belajar baru yang sesuai dengan tema pembelajaran. Selain itu, guru juga belum bisa mengembangkan media pembelajaran yang bervariatif sehingga menyebabkan anak kurang terarik dalam belajar. Hal ini menyebabkan kurang optimalnya perkembangan motorik halus pada anak.

Berdasarkan permasalahan tersebut, maka solusi yang dapat ditawarkan yaitu dengan mengembangkan media pembelajaran inovatif. Media pembelajaran merupakan segala sesuatu yang dapat digunakan sebagai bahan belajar pada anak (Aprinawati, 2017; Putri et al., 2020; Susiani et al., 2013). Media pembelajaran juga sebagai sarana komunikasi non-verbal sehingga penyampaian materi melalui media lebih menarik bagi anak. Media pembelajaran yang inovatif dapat meningkatkan semangat siswa dalam belajar (Solihati, 2015; Yusnia, 2019). Sehingga media pembelajaran memiliki peranan yang sangat penting terutama pada anak usia dini (Oktarina \& Liyanovitasari, 2019). Berbagai variasi media akan berpengaruh terhadap hasil belajar anak usia dini (Hardiyanti et al., 2018; Marini, 2015). Penggunaan media juga dapat membangkitkan motivasi belajar terutama pada anak usia dini. Media pembelajaran ini dapat menjadi fasilitas belajar anak yang memudahkan anak dalam memahami materi pembelajaran. Salah satu media yang dapat dikembangkan untuk meningkatkan kemampuan anak yaitu media papercraft. Papercraft merupakan seni merakit kertas dari lembaran kertas yang menggunakan teknik menggunting, melipat, dan membentuk kertas (Jasmine, 2018; Nurjannah, 2018). Media papercraft merupakan salah satu alternatif media untuk menstimulasi kemampuan menggunting pada anak. Kemampuan motorik halus pada anak akan semakin kuat dengan kegiatan ini (Utomo et al., 2018; Wandi \& Mayar, 2019). Meningkatkan kemampuan motorik halus pada anak usia dini harus melibatkan penggunaan tangan dan jari secara baik seperti menulis dan menggambar. Kemampuan motorik halus ini berfokus pada kemampuan koordinasi tangan dengan mata (Ulfah et al., 2021; Wandi \& Mayar, 2019). Kegiatan menggunting salah satu kegiatan yang dapat menstimulasi kemampuan motorik halus pada anak. Kegiatan menggunting dapat diberikan kepada anak yang dapat diawali dengan beberapa tahapan seperti menggunting secara bebas, kemudian tahapan menggunting yang disesuaikan dengan bentuk pola tertentu seperti persegi, segitiga, ataupun bulat pada kertas (Nurhidayat et al., 2020). Kegiatan seperti ini akan menciptakan suasana belajar yang menyengkan bagi siswa sehingga dapat meningkatkan kemampuan motorik pada anak usia dini (Nurjani, 2019).

Temuan penelitian sebelumnya mengenai motorik halus pada anak menyatakan bahwa media pembelajaran yang menarik dapat menstimulasi motorik halus pada anak usia dini (Nurwita, 2019; Tanto \& Sufyana, 2020). Penelitian lainnya juga menyatakan bahwa media pembelajaran yang relevan dapat meningkatkan motoric halus pada anak (Darmiatun \& Mayar, 2019; Tanto \& Sufyana, 2020). Temuan penelitian lainnya juga menyatakan bahwa media papercraft dapat membantu siswa dalam belajar sehingga dapat meningkatkan kemampuan anak usia dini (Nurjannah, 2018). Kelemahan dari penelitian sebelumnya yaitu penggunaan media pembelajaran tidak melibatkan kemampuan motorik anak secara maksimal sehingga pembelajaran tidak mencapai tujuan yang maksimal. Selain itu, belum adanya penelitian media papercraft yang dapat menstimulasi motorik anak usia dini. Kelebihan media yang akan dikembangkan yaitu media ini menggunakan contoh gambar yang menarik dan inovatif yang mampu merangsang minat siswa dalam belajar. Papercraft dapat dibuat menyesuaikan dengan tema yang ada di sekolah yaitu tema binatang sehingga anak dapat mengenal beragam jenis nama-nama hewan dan dapat 
belajar mengenal warna. Selain itu, penggunaan media belajar seperti bermain dapat menciptakan suasana belajar pada anak. Penelitian ini bertujuan untuk mengembangkan media papercraft yang dapat meningkatkan kemampuan menggunting pada anak. Media yang dikembangkan ini diharapkan dapat meningkatkan kemampuan menggunting pada anak, sehingga dapat menstimulasi perkembangan motorik halus pada anak.

\section{METODE}

Jenis penelitian ini yaitu penelitian pengembangan (Research and Development). Model yang digunakan dalam penelitian ini yaitu ADDIE yang meliputi tahapan analysis, design, development, implementation, evaluation (Pramana et al., 2020). Penggunaan model ADDIE pada penelitian ini dikarenakan atas pertimbangan model ini sistematis dan mudah untuk dimengerti. Adapun desain model ADDIE tersaji pada gambar 1 .

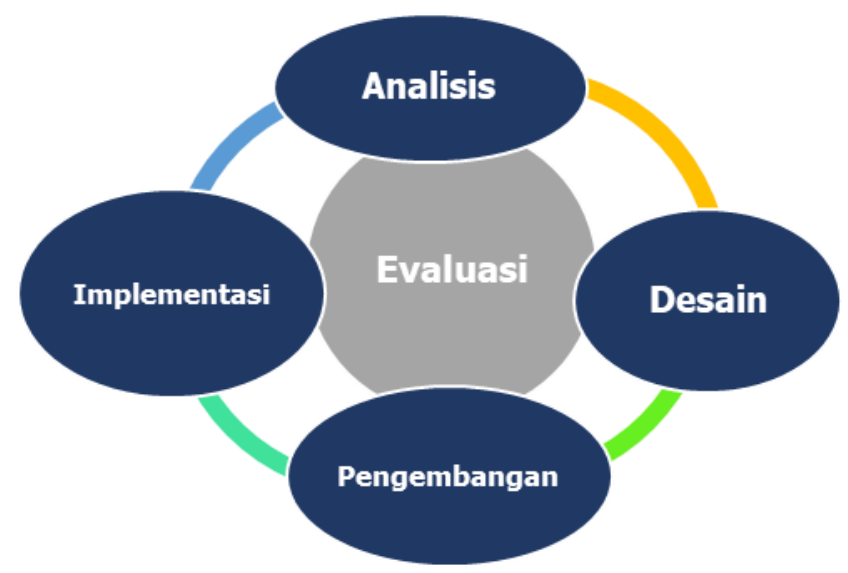

Gambar 1. Rancangan penelitian dengan Model ADDIE (Hakiki, 2016)

Subyek penelitian ini berjumlah 4 orang ahli yang merupakan 2 orang ahli media pembelajaran dan 2 orang ahli materi pelajaran. Teknik yang digunakan dalam mengumpulkan data pada penelitian ini yaitu observasi, wawancara, kuesioner, dan dokumentasi. Observasi dan wawancara digunakan untuk mengetahui masalah yang tejadi dalam pembelajaran anak usia dini. Metode kuesioner digunakan untuk mengetahui validitas media papercraft yang akan dikembangkan. Dokumentasi digunakan untuk merekap pelaksanaan pengembangan media. Instrument yang digunakan dalam mengumpulkan data pada penelitian ini yaitu kuesioner. Adapun kisi-kisi instrumen yang dikembangkan disajikan pada tabel 1 dan 2.

Tabel 1. Kisi-Kisi Instrumen untuk Uji Ahli Materi Pelajaran

\begin{tabular}{|c|c|c|}
\hline No & Dimensi & Indikator \\
\hline 1. & Isi materi & $\begin{array}{l}\text { 1. Daya dukung materi terhadap stimulasi kemampuan } \\
\text { menggunting anak }\end{array}$ \\
\hline & & $\begin{array}{l}\text { 2. Kesesuaian materi dengan tingkat pencapaian perkembangan } \\
\text { anak }\end{array}$ \\
\hline 2. & Tujuan & $\begin{array}{l}\text { 3. Kesesuaian materi dengan tujuan pembelajaran yaitu } \\
\text { meningkatkan kemampuan menggunting anak }\end{array}$ \\
\hline & & $\begin{array}{l}\text { 4. Kejelasan materi yang disampaikan dalam media } \\
\text { pembelajaran }\end{array}$ \\
\hline 3. & Motivasi & $\begin{array}{l}\text { 5. Penyajian materi memotivasi anak untuk belajar } \\
\text { 6. Penyajian materi menarik minat anak untuk belajar }\end{array}$ \\
\hline
\end{tabular}

(Suartama, 2016)

Tabel 2. Kisi-Kisi Instrumen untuk Uji Ahli Media Pelajaran

\begin{tabular}{cccc}
\hline No & & Dimensi & Indikator \\
\hline 1. & Fisik & 1. & Kemenarikan desain media papercraft
\end{tabular}




\begin{tabular}{llll}
\hline \multirow{2}{*}{ 2. Gambar } & 2. & Ketepatan memilih jenis kertas cetak \\
& & 3. & Kejelasan bentuk gambar \\
3 & Warna & 5. & Kesesuaian gambar dengan materi pembelajaran \\
& & 6. & Kesesuaian komposisi warna dengan gambar pola \\
\hline
\end{tabular}

(Suartama, 2016)

Uji validitas instrumen dilakukan untuk mengetahui kelayakan dari instrumen yang akan dipakai dalam meningkatkan kemampuan menggunting anak. Validitas instrumen kemampuan menggunting menggunakan perhitungan validitas isi dari Gregory. Penelitian ini menggunakan analisis data kualitatif dan kuantitatif. Data kualitatif di sini berupa hasil wawancara, kritik, saran dari narasumber, sedangkan data kuantitatif berupa angket kisi-kisi instrumen ahli media dan ahli materi yang digunakan untuk mengetahui kelayakan produk media papercraft. Analisis validasi pengembangan media papercraft menggunakan metode analisis Content Validity Ratio (CVR).

\section{HASIL DAN PEMBAHASAN}

\section{Hasil}

Tahapan pengembangan media papercraft menggunakan model pengembangan ADDIE. Adapun prosesur pengembangan media papercraft dimulai pada tahap analisis, desain, pengembangan, implementasi, dan evaluasi. Namun terdapat tahapan yang tidak terlaksana yaitu tahap implementasi dan evaluasi. Hal ini dikarenakan pandemic covid-19 dimana proses pembelajaran yang mengharuskan anakanak untuk belajar dari rumah, keterbatasan waktu, sumber daya, dan tenaga. Pemaparan hasil dari setiap tahapan yaitu sebagai berikut. Tahap pertama yaitu analisis. Pada tahap ini dilakukan analisis kebutuhan anak usia dini dan analisis media untu mengetahui potensi serta masalah yang sedang terjadi. Permasalahan yang di dapat dari hasil wawancara dan pengumpulan informasi pada kelompok A yaitu anak masih kesulitan dalam hal memegang gunting, mengerakkan gunting serta menggunting sesuai dengan pola, sehingga perlunya media pembelajaran yang dapat meningkatkan kemampuan menggunting anak. Dari hasil analisis kebutuhan tersebut maka solusi yang ditawarkan membuat pengembangan media papercraft. Diharapkan dengan digunakannya media papercraft, dapat memenuhi kebutuhan pembelajaran anak kelompok A TK Negeri Desa Tukadmungga. Tahap kedua yaitu desain. Pada tahap ini yaitu mendesain media papercraft yang akan dikembangkan. Perancangan media papercraft dilakukan agar dapat digunakan sesuai dengan tujuan pembelajaran. Sebagai langkah awal dalam pengembangan media papercraft peneliti terlebih dahulu membuat rancangan media, rancangan materi untuk kegiatan belajar mengajar dan menetapkan tujuan pembelajaran. Adapun desain media papercraft yang akan dikembangkan tersaji pada gambar 1.
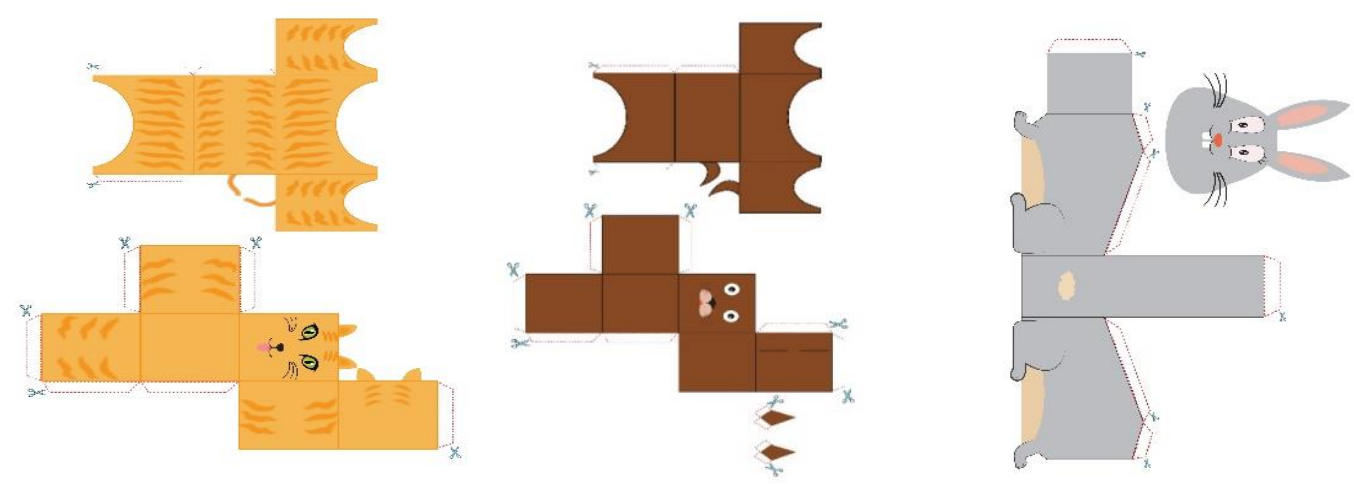

Gambar 1. Desain Media Papercraft

Tahap ketiga yaitu pengembangan. Pada tahap ini dilakukan pengembangan media papercraft. Adapun hasil pengembangan media papercraft tersaji pada gambar 2. 


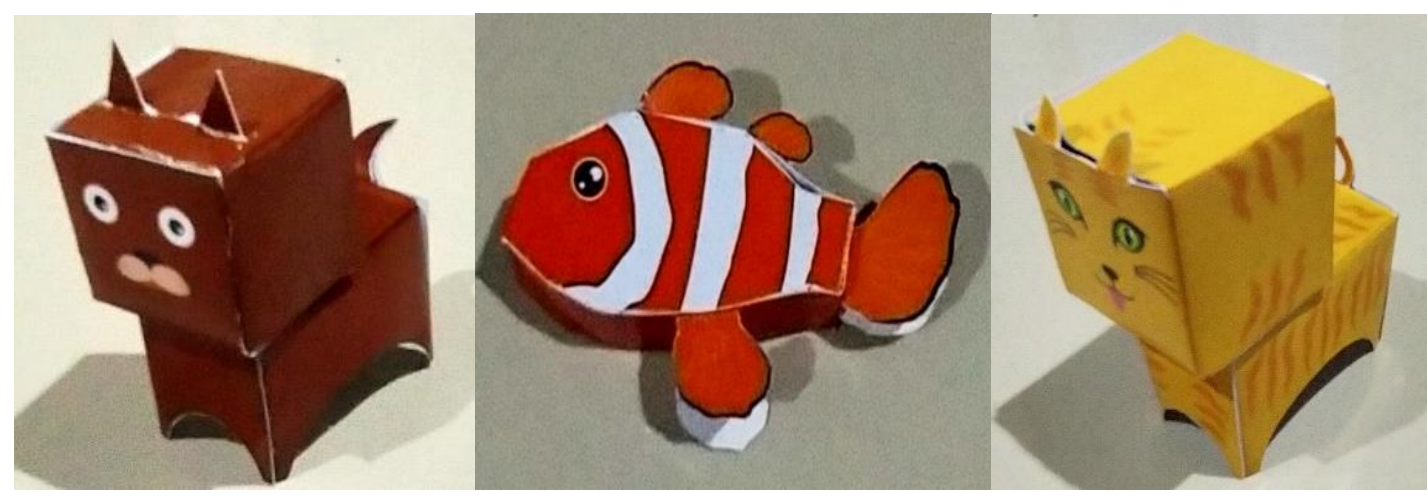

Gambar 2. Media Papercraft yang Dikembangkan

Setelah media pembelajaran papercraft dikembangkan, selanjutnya yaitu media papercraft ini akan diuji validitasnya oleh ahli isi pelajaran dan media pembelajaran. Berdasarkan hasil uji dari ahli isi mata pelajaran, media yang dikembangkan berupa media papercraft mendapatkan hasil validitas 1,00 maka dapat disimpulkan bahwa materi tersebut valid dan mendapatkan kriteria sangat tinggi, sehingga layak diterapkan pada anak usia dini. Hasil uji dari ahli media pembelajaran yaitu media yang dikembangkan berupa media papercraft mendapatkan hasil validitas 1,00 maka dapat disimpulkan bahwa materi tersebut valid dan mendapatkan kategori sangat tinggi sehingga layak diterapkan pada anak usia dini. Media yang dikembangkan mendapatkan kategori sangat tinggi sehingga tidak ada masukan ataupun saran dari para ahli untuk merevisi produk yang dikembangkan. Sehingga disimpulkan bahwa media pembelajaran berupa media papercraft yang dikembangkan layak diterapkan dalam proses pembelajaran. Hal ini dikarenakan oleh beberapa faktor yaitu sebagai berikut.

Pertama, media papercraft mendapatkan kualifikasi sangat tinggi sehingga layak diterapkan dalam proses pembelajaran karena media papercraft dapat meningkatkan minat dan motivasi siswa dalam belajar. Pengembangan media papercraft layak diterapkan disebabkan dari aspek fisik seperti kemenarikan, dan kejelasan media. Media pembelajaran yang menarik dapat meningkatkan motivasi siswa dalam belajar (Chang et al., 2020; Heo \& Toomey, 2020). Selain itu penyajian materi yang jelas juga menambah ketertarikan siswa dalam menggunakan media tersebut (Sunismi, 2015; Yusnia, 2019). Media pembelajaran yang dikemas dengan baik dapat menyampaikan informasi yang baik pula pada pengguna. Hal ini juga sesuai teori yang menyatakan media pembelajaran yang telah melalui proses validitas dan mendapatkan kualifikasi sangat tingga dapat membantu siswa dalam belajar (Gunawan, Sahidu, Harjono, \& Suranti, 2017; Putra, Handarini, \& Ramli, 2019). Media papercraft ini mengajak keterlibatan anak secara penuh sehingga anak merasa tidak bosan dalam belajar. Selain itu tokoh atau karakter pada media ini sangat menarik sehingga membuat motivasi belajar anak usia dini juga meningkat. Hal ini yang menyebabkan media papercraft memotivasi dan meninkatkan minat siswa dalam belajar.

Kedua, media papercraft mendapatkan kualifikasi sangat tinggi sehingga layak diterapkan dalam proses pembelajaran karena media papercraft dapat menstimulasi kemampuan motorik halus pada anak usia dini. Papercraft merupakan media pembelajaran yang dapat digunakan agar proses pembelajaran menjadi lebih efektif (Jasmine, 2018; Nuzulia, 2016). Media papercraft ini membuat anak dapat membuat berbagai macam bentuk sesuai dengan keinginan. Hal tersebut dapat memberikan stimulasi dalam mengembangkan kemampuan motorik halus seperti kemampuan menggunting, menempel, dan melipat. Media pembelajaran ini dapat membantu anak dalam meningkatkan kemampuan mengguntingnya (Jasmine, 2018; Triwijaya, 2014). Kemampuan menggunting merupakan kemampuan dasar anak agar nantinya dapat menyelesaikan aktivitas/kegiatan yang lebih kompleks. Kemampuan menggunting dapat meningkatkan motorik halus pada anak. Gerakan meraih dan menggenggam suatu benda merupakan perkembangan awal fisik motorik halus anak, semakin banyak anak bergerak maka akan semakin terampil menguasai gerakan fisik motoriknya (Lestariani et al., 2019; Nurjannah, 2018; Wandi \& Mayar, 2019). Dalam membentuk papercraft tingkat kesulitan yang dihadapi bervariasi mulai dari bentuk sederhana hingga bentuk yang lebih kompleks di mana saat membuatnya membutuhkan fokus, kesabaran, dan ketelitian. Gerakan halus yang dilakukan saat latihan menggunting, nantinya akan membantu anak untuk lebih mudah belajar menulis. Selain itu menggunting dapat menjadi salah satu sarana anak untuk mengungkapkan ekspresi dan kreativitasnya. Kemampuan menggunting yang distimulasi akan memudahkan anak untuk mengikuti kegiatan di sekolah seperti menulis, menggambar, mewarnai, menggenggam benda, dan beragam kegiatan yang membutuhkan kekuatan jari-jemari tangan anak.

Ketiga, media papercraft mendapatkan kualifikasi sangat tinggi sehingga layak diterapkan dalam proses pembelajaran karena media papercraft dapat menciptakan suasana belajar yang menyenangkan 
bagi anak. Melalui papercraft anak dapat belajar mengenal warna, bentuk, nama hewan, nama macammacam benda langit, nama buah ataupun nama-nama kendaraan. Media papercraft mampu meningkatkan konsentrasi dan imajinasi anak sehingga menciptakan suasana belajar yang menyenangkan. Media pembelajaran yang menarik akan memberikan suasana belajar yang menyenangkan bagi siswa (Alviolita \& Huda, 2019; Silmi \& Rachmadyanti, 2018; Tri Sutrisno, 2016). Dalam proses pembuatan media papercraft anak akan diarahkan dan dibimbing untuk menggunting sesuai pola yang sudah dibuat. Kertas yang digunakan dalam media ini menggunakan perpaduan warna yang berbeda sehingga membuat siswa merasa tertarik dalam belajar. Penggunaan warna pada media yang benar akan meningkatkan semangat siswa dalam belajar sehingga menciptakan suasana belajar yang menyenangkan (Aprinawati, 2017; Arif \& Samidjo, 2018; Dianawati, 2019). Hal tersebut yang menciptakan suasana belajar anak usia dini menjadi nyaman serta menyenangkan sehingga berdampak pada pemahaman anak yang meningkat.

Temuan penelitian sebelumnya menyatakan bahwa motorik halus anak akan meningkatkan jika melibatkan indra siswa dalam belajar melalui media pembelajaran (Tanto \& Sufyana, 2020; Ulfah et al., 2021). Temuan penelitian lainnya juga menyatakan bahwa media papercraft membuat siswa lebih termotivasi dalam belajar dan menciptakan suasana belajar yang menyenangkan (Nuzulia, 2016; Triwijaya, 2014). Kelebihan media yang dikembangkan yaitu media papercraft menggunakan contoh gambar yang menarik sehingga merangsang minat siswa dalam belajar. Media ini juga menggunakan contoh gambar hewan sehingga media ini juga dapat mengenalkan jenis-jenis hewan pada anak. Kontribusi penelitian ini media papercraft dapat meningkatkan semangat anak usia dini dalam belajar sehingga berpengaruh pada peningkatan motorik halus pada anak. Keterbatasan penelitian ini hanya sampai uji validitas produk tetapi tetap layak digunakan. Implikasi penelitian ini yaitu media pembelajaran berupa media papercraft ini dapat dimanfaatkan pembelajaran anak usia dini, sehingga melalui media pembelajaran ini siswa dapat belajar secara mandiri di rumah dengan pengawasan orang tua.

\section{SIMPULAN}

Berdasarkan hasil analisis data media papercraft mendapatkan kualifikasi sangat tinggi. Dapat disimpulkan bahwa media papercraft layak untuk anak usia dini dalam proses pembelajaran. Media papercraft ini juga membantu guru dalam mengajar sehingga anak dapat meningkatkan kemampuan motorik halus dengan menggunakan media ini.

\section{DAFTAR RUJUKAN}

Aisyah, A. (2017). Permainan Warna Berpengaruh Terhadap Kreativitas Anak Usia Dini. Jurnal Obsesi : Jurnal Pendidikan Anak Usia Dini, 1(2), 118. https://doi.org/10.31004/obsesi.v1i2.23.

Alviolita, N. W., \& Huda, M. (2019). Media Pop Up Book Dalam Pembelajaran Bercerita. Jurnal Pendidikan Bahasa Indonesia, 7(1), 49. https://doi.org/10.30659/j.7.1.49-57.

Aprinawati, I. (2017). Penggunaan Media Gambar Seri Untuk Meningkatkan Kemampuan Berbicara Anak Usia Dini. Jurnal Obsesi: Jurnal Pendidikan Anak Usia Dini, 1(1), 72. https://doi.org/10.31004/obsesi.v1i1.33.

Arif, L., \& Samidjo, S. (2018). Hubungan Antara Sikap Belajar Dan Motivasi Belajar Kejuruan Dengan Hasil Belajar Gambar Teknik. TAMAN VOKASI, 6(1), 92. https://doi.org/10.30738/jtvok.v6i1.2865.

Chang, T. Y., Hong, G., Paganelli, C., Phantumvanit, P., Chang, W. J., Shieh, Y. S., \& Hsu, M. L. (2020). Innovation of dental education during COVID-19 pandemic. Journal of Dental Sciences, 155. https://doi.org/10.1016/j.jds.2020.07.011.

Darmiatun, S., \& Mayar, F. (2019). Meningkatkan Kemampuan Motorik Halus Anak melalui Kolase dengan Menggunakan Bahan Bekas pada Anak Usia Dini. Jurnal Obsesi : Jurnal Pendidikan Anak Usia Dini, 4(1), 257. https://doi.org/10.31004/obsesi.v4i1.327.

Dianawati, E. P. (2019). Pengaruh Media Tebak Gambar dan Talking Stick Terhadap Motivasi Belajar Siswa. Jurnal Ilmiah WUNY, 1(1). https://doi.org/10.21831/jwuny.v1i1.26855.

Gunawan, G., Sahidu, H., Harjono, A., \& Suranti, N. M. Y. (2017). Efektivitas Penerapan Model Project Based Learning Berbantuan Media Virtual terhadap Kreativitas Fisika Peserta Didik. Jurnal Cakrawala Pendidikan, 36(2). https://doi.org/10.21831/cp.v36i2.13514.

Hakiki, R. W. (2016). Pengembangan Media Pembelajaran Matematika Berbantu Wondershare Dengan Pendekatan Rme Pada Materi Smp. Aksioma, 7(2), 91. https://doi.org/10.26877/aks.v7i2.1425.

Harahap, S. A., Dimyati, D., \& Purwanta, E. (2021). Problematika Pembelajaran Daring dan Luring Anak Usia Dini bagi Guru dan Orang tua di Masa Pandemi Covid 19. Jurnal Obsesi : Jurnal Pendidikan Anak Usia Dini, 5(2), 1825-1836. https://doi.org/10.31004/obsesi.v5i2.1013. 
Hardiyanti, Y., Husain, M. S., \& Nurabdiansyah, N. (2018). Perancangan Media Pengenalan Warna Untuk Anak Usia Dini. JURNAL IMAJINASI, 2(2), 43. https://doi.org/10.26858/i.v2i2.9553.

Heo, M., \& Toomey, N. (2020). Learning with multimedia: The effects of gender, type of multimedia learning resources, and spatial ability. Computers and Education, 146, 103747. https://doi.org/10.1016/j.compedu.2019.103747.

Iswantiningtyas, V., \& Wulansari, W. (2018). Pengembangan Model Penilaian Pendidikan Karakter Anak Usia Dini. JPUD - Jurnal Pendidikan Usia Dini, 12(2), 361-370. https://doi.org/10.21009/jpud.122.17.

Jasmine, C. V. (2018). Pengembangan Papercraft Sebagai Media Pembelajaran Pengenalan Alam Semesta Pada Anak Kelompok B Tk Kartika Iv-89 Bangkalan. Jurnal Seni Rupa, 6(2).

Lestariani, L. P., Mahadewi, L. P. P., \& Antara, P. A. (2019). Pengaruh Model Pembelajaran Tari Kreatif terhadap Kemampuan Motorik Kasar Kelompok B Gugus I Kecamatan Banjar. Jurnal Pendidikan Anak Usia Dini Undiksha, 7(3), 236-245. https://doi.org/10.23887/paud.v7i2.19010.

Mardliyah, S., Yulianingsih, W., \& Putri, L. S. R. (2020). Sekolah Keluarga: Menciptakan Lingkungan Sosial untuk Membangun Empati dan Kreativitas Anak Usia Dini. Jurnal Obsesi : Jurnal Pendidikan Anak Usia Dini, 5(1), 576. https://doi.org/10.31004/obsesi.v5i1.665.

Marini, K. K. P. dan N. M. A. (2015). Penerapan Metode Bercerita Berbantuan Media Boneka Tangan Untuk Meningkatkan Keterampilan Berbicara Pada Anak Kelompok B3. E-Journal PG PAUD Universitas Pendidikan Ganesha: Jurusan Pendidikan Guru Pendidikan Anak Usia Dini, 3(1), 4. https://doi.org/10.23887/paud.v2i1.3239.

Mundia Sari, K., \& Setiawan, H. (2020). Kompetensi Pedagogik Guru dalam Melaksanakan Penilaian Pembelajaran Anak Usia Dini. Jurnal Obsesi: Jurnal Pendidikan Anak Usia Dini, 4(2), 900. https://doi.org/10.31004/obsesi.v4i2.478.

Nurhidayat, N., Afiif, A., \& Patiung, D. (2020). Meningkatkan Kemampuan Motorik Halus Melalui Kegiatan Menggunting Pada Anak Usia Dini Di Kelompok A TK Khadijah Surabaya. NANAEKE: Indonesian Journal of Early Childhood Education, 3(2), 101. https://doi.org/10.24252/nananeke.v3i2.16130.

Nurjani, Y. Y. (2019). Upaya Mengembangkan Motorik Halus Anak Usia Dini Melalui Kegiatan Menggunting. Journal of SPORT (Sport, Physical Education, Organization, Recreation, and Training), 3(2), 85-92. https://doi.org/10.37058/sport.v3i2.1026.

Nurjannah, D. (2018). Peningkatan Motorik Halus Anak Melalui Kegiatan Bermain Papercraft (Penelitian Tindakan di TK Alam Rizkia, Depok). Al-Athfal: Jurnal Pendidikan Anak, 4(2), 149-160. https://doi.org/10.14421/al-athfal.2018.42-03.

Nurwita. (2019). Pemanfaatan Media Puzzle Dalam Mengembangkan Motorik Halus Anak di PAUD Aiza Kabupaten Kepahiang. Jurnal Pendidikan Tambusai., 808. https://doi.org/10.31004/jptam.v2i4.285.

Nuzulia, D. (2016). Pengaruh Penggunaan Media Diorama Papercraft Terhadap Kemampuan Menulis Cerpen Siswa Kelas X Sma Negeri 10 Palembang. Jurnal Ilmu Kependidikan, 4(1). https://doi.org/10.31851/wahanadidaktika.v14i1.564.

Oktarina, N. D., \& Liyanovitasari, L. (2019). Media Cerita Bergambar Tentang Pengenalan Seks Dini Meningkatkan Pengetahuan Anak Usia Dini. Jurnal Kesehatan Perintis (Perintis's Health Journal), 6(2), 110-115. https://doi.org/10.33653/jkp.v6i2.296.

Pramana, Jampel, \& Pudjawan. (2020). Meningkatkan Hasil Belajar Biologi Melalui E-Modul Berbasis Problem Based Learning. Jurnal Edutech Undiksha, 8(2), 18-32. https://doi.org/10.23887/jeu.v8i2.28921.

Pratiwi, D. A., \& Rahmah, L. (2019). Implementasi Model Pembelajaran Sentra Main Peran untuk Mengembangkan Motorik Halus AUD. Golden Age: Jurnal Ilmiah Tumbuh Kembang Anak Usia Dini, 3(3), 181-190. https://doi.org/10.14421/jga.2018.33-04.

Putra, A. T., Handarini, D. M., \& Ramli, M. (2019). Media Wayang Golek untuk Menumbuhkan Kesadaran Menyelesaikan Konflik secara Konstruktif bagi Siswa SMP. Jurnal Pendidikan: Teori, Penelitian, Dan Pengembangan, 4(11), 1478. https://doi.org/10.17977/jptpp.v4i11.13006.

Putri, D. K., Handayani, M., \& Akbar, Z. (2020). Pengaruh Media Pembelajaran dan Motivasi Diri terhadap Keterlibatan Orang Tua dalam Pendidikan Anak. Jurnal Obsesi : Jurnal Pendidikan Anak Usia Dini, 4(2), 649. https://doi.org/10.31004/obsesi.v4i2.418.

Silmi, M. ., \& Rachmadyanti, P. (2018). Pengembangan Media Pembelajaran Video Animasi Berbasis Sparkol Videoscribe Tentang Persiapan Kemerdekaan RI SD Kelas V.Jpgsd, 6(4).

Solihati, A. (2015). Efektifitas Media Panggung Boneka untuk Meningkatkan Kemampuan Bercerita pada Anak Usia Dini. SELING: Jurnal Program Studi PGRA, 1(1), 41-53. https://doi.org/10.2345/modeling.v2i2.2176.

Suartama, I. K. (2016). Evaluasi dan Kriteria Kualitas Multimedia Pembeajaran (Issue January 2016). 
Universitas Pendidikan Ganesha.

Sunismi. (2015). Developing Guided Discovery Learning Materials Using Mathematics Mobile Learning Application As An Alternative Media For The Students Calculus II. Cakrawala Pendidikan, 34(3), 334-346. https://doi.org/10.21831/cp.v3i3.7340.

Susiani, P. E., Pudjawan, K., \& Renda, N. T. (2013). Penerapan Metode Role Playing Berbantuan Media Boneka Gambar Untuk Meningkatkan Kemampuan Bahasa Indonesia Anak Kelompok B TK Satya Kumara. Jurnal Pendidikan Anak Usia Dini Undiksha, 1(1). https://doi.org/10.23887/paud.v1i1.1138.

Tanto, O. D., \& Sufyana, A. H. (2020). Stimulasi Perkembangan Motorik Halus Anak Usia Dini dalam Seni Tradisional Tatah Sungging. Jurnal Obsesi: Jurnal Pendidikan Anak Usia Dini, 4(2). https://doi.org/https://doi.org/10.31004/obsesi.v4i2.421.

Tri Sutrisno, Y. A. A. (2016). Pengembangan Media Videoscribe Berbasis E-Learning pada Mata Pelajaran Komunikasi Data Interface di SMK Sunan Drajat Lamongan. Jurnal Pendidikan Teknik Elektro, 5(3), 1. https://jurnalmahasiswa.unesa.ac.id/index.php/jurnal-pendidikan-teknikelektro/article/view/17213/15652.

Triwijaya, H. (2014). Pengaruh Pembelajaran Seni Papercraft Terhadap Kemampuan Motorik Halus Anak Tunadaksa Kelas II di SDLB D/D1 YPAC Kota Malang. In Kependidikan Sekolah Dasar (Vol. 1, Issue 1).

Ulfah, A. A., Dimyati, D., \& Putra, A. J. A. (2021). Analisis Penerapan Senam Irama dalam Meningkatkan Kemampuan Motorik Kasar Anak Usia Dini. Jurnal Obsesi : Jurnal Pendidikan Anak Usia Dini, 5(2), 1844-1852. https://doi.org/10.31004/obsesi.v5i2.993.

Utomo, I. A., Ramli, M., \& Furaidah, F. (2018). Penerapan Strategi Bermain melalui Media Busy Book untuk Meningkatkan Fisik Motorik Halus Anak Usia Dini. Jurnal Pendidikan: Teori, Penelitian, Dan Pengembangan, 3(12), 1594-1598. https://doi.org/10.17977/jptpp.v3i12.12553.

Wandi, Z. N., \& Mayar, F. (2019). Analisis Kemampuan Motorik Halus dan Kreativitas pada Anak Usia Dini melalui Kegiatan Kolase. Jurnal Obsesi: Jurnal Pendidikan Anak Usia Dini, 4(1), 363. https://doi.org/10.31004/obsesi.v4i1.347.

Wulandari, A., \& Suparno, S. (2020). Pengaruh Model Problem Based Learning terhadap Kemampuan Karakter Kerjasama Anak Usia Dini. Jurnal Obsesi : Jurnal Pendidikan Anak Usia Dini, 4(2), 862. https://doi.org/10.31004/obsesi.v4i2.448.

Yusnia, Y. (2019). Penggunaan Media Video Scribe Dalam Pembelajaran Literasi Sains Untuk Mahasiswa PGPAUD. Cakrawala Dini: Jurnal Pendidikan Anak Usia Dini, 10(1), 71-75. https://doi.org/10.17509/cd.v10i1.17436. 